\title{
Cottbus 2004
}

\author{
By Ron Holloway
}

Fall 2004 Issue of KINEMA

\section{COTTBUS FESTIVAL OF EAST EUROPEAN FILMS 2004}

No other European festival is better positioned than Cottbus to measure the depth and range of the current film revival in Central and Eastern Europe. Abetted by the smart programming skill of festival director Roland Rust, the $14^{\text {th }}$ Filmfestival Cottbus (2-6 November 2004) - aka the $14^{\text {th }}$ Festival of East European Cinema - was again a must-visit event for critics, cineastes, and directors interested in keeping apace with the hundred or more important productions released annually in filmlands stretching from the former German Democratic Republic to Kazakhstan in Central Asia. This year, with its generous budget of circa 500,000 Euros from Land Brandenburg and the City of Cottbus, the festival staff made absolutely sure that its double competition for features and shorts under separate juries had selected the best entries from a bumper crop of quality productions in a dozen rejuvenated filmlands. In addition, the festival Focus on New Czech Cinema was particularly opportune in view of the recent entry of the Czech Republic into the European Union last May.

Guka (Gulshad) Omarova's Schiza (Schizo), a debut feature shot in Kazakhstan in coproduction with Russia, France, and Germany, was awarded the Main Prize for Best Film and the Don Quixote Prize by International Federation of Film Clubs. First seen last May in the Un Certain Regard section at Cannes, Schizo went on from there to receive the Best Debut Film award at Sochi and win critical praise in the East of the West section at Karlovy Vary. Born 1968 in Almaty (aka Alma Ata, the former capital of Kazakhstan), Omarova acted in films as a teenager, studied journalism and film directing, made shorts and documentaries for television, and collaborated with Sergei Bodrov Sr on the screenplay for the late Sergei Bodrov Jr's Sisters (2001). Schizo, coproduced and coscripted by Sergei Bodrov Sr, is set in Kazakhstan in the early 1990s, a time and place Bodrov knows like the back of his hand - going back in 1985, when he made The Non-Professionals, a low-budget independent production, without state support or official government permission. The story of a 15-year-old lad on his own and nicknamed "Schizo" by school chums due to his clumsy manners, Mustafa learns the trade of illegal boxing matches firsthand, promises a dying boxer to give his hard-earned money to a young mother, and then turns the tables on the boxing mafia by resorting to a few tricks of own. Narrated with a light hand for character and atmosphere, Schizo confirms Guka Omarova as talent to watch on the Central Asian scene.

Awarded the Special Prize for Best Director, Sulev Keedus's remarkable Somnambuul (Broken Sleep, 2003), an Estonian coproduction with Finland, was some time in coming due to the rigours of shooting in an isolated location. A portrait of anxiety and loneliness, Broken Sleep, filmed on an island in the Baltic Sea off the coast of Estonia, picks up where the director's Georgica (1998) had previously left off five years ago. Georgica, in turn, was evidently Keedus's homage and response to Andrei Tarkovsky's Stalker (USSR, 1979). Set in the autumn of 1944, when hundreds of Estonians attempted to escape Communist repression by sailing across the breadth of the Baltic Sea to Sweden, Broken Sleep, a psychological drama, tells the story of Eetla (Katariina Lauk-Tamm), whose attempts to leave her dominating father, the keeper of a lighthouse on a godforsaken island, drive her deeper and deeper into insanity - until, one day, a stranger enters her world of distorted dreams and fantasies. If nothing else, Broken Sleep - like Stalker as well - scores as a dark, dismal, depressing metaphor on the political turmoil of the times.

The Special Prize for Outstanding Artistic Contribution was awarded to Arsen Anton Ostojic's Ta divna Splitska noc (A Wonderful Night in Split, Croatia), an interlocking and overlapping black-and-white film constructed around three different stories, each with fatal consequences, that take place between $10 \mathrm{pm}$ and midnight on a New Year's Eve in the narrow streets and corridors of Diocletian's Palace on the Adriatic Coast. Previously awarded the Special Jury Prize at the Sarajevo festival, A Wonderful Night in Split introduces another talented filmmaker making his feature film debut. Born1965 in Split, Arsen Anton Ostojic graduated from the film department at New York University, directed a handful of awarded shorts, and now is being ranked with Vinko Bresan (Witnesses, 2003) as a pacesetting filmmaker to watch in New Croatian Cinema. 
Hungarian cinema is also riding a way of critical successes and festival hits by newcomers. After Kornel Mundruczo (Pleasant Days, 2002), György Palfi (Hiccups, 2002), and Benedek Fliegauf (Forest, 2003), now comes Antal Nimrod, whose Kontroll (Control, 2003) was awarded the prestigious Gene Moskowitz Critics Prize at the Hungarian Film Days, rose to become the top Hungarian box office hit of the season, and was awarded no less than three prizes at Cottbus: the FIPRESCI (International Critics) Prize, the Ecumenical Prize, and the Student Jury Award. Born 1973 in Los Angeles, Nimrod studied cinema at the Pasadena Art Center before returning to Hungary to enroll in the Budapest Film School. His graduation short, Insurance (1998), chronicled the adventures of "crashers" who demolish cars to collect accident insurance money. Generally despised by the public for their shake-down methods, they are always on the run from inspectors. Some of these weird anti-heroes were to turn up later in Control, albeit in a slightly different though comparable guise as ticket inspectors. Set entirely in the dark labyrinth of the Budapest metro system, we are at first entertained by the antics of somewhat deranged control inspectors during their routines on a metro line. Explosive encounters with hostile riders are, of course, to be expected. But then, when a mysterious hooded serial killer continues to push people under trains, we are not sure if we are watching a deftly constructed psychological thriller or a film metaphor about social misfits who can't deal with reality in the above-ground everyday. Probably both.

The surprise hit of the current Czech season is a documentary! Vít Klusák and Filip Remunda, graduates of the Prague Film School (FAMU), hit the jackpot with Český sen (Czech Dream), a free-flowing, hilarious document about the marketing of a consumer hoax. For two weeks in May of 2003, the Prague public was saturated with advertising about the opening of a "hypermarket for better life" - a kind of super-store catering to eager-beaver shoppers. Of course, as one might suspect, a crowd of several thousand showed up on an open field on a bright sunny day waiting for the ribbon to be cut before a huge sign upon which was emblazoned the "Czech Dream" logo. Some shoppers even arrived at dawn with camping-chairs to be the first in line for the grand opening! A delight to watch as the hoax unfolds, Czech Dream went on from there to provoke hefty pro-and-contra opinions in the media, an open-ended debate in the Czech Parliament, and some threats to "get even" with the filmmakers for playing a dirty trick on the naive and guileless public. Apparently propagating dreams on the media can be dangerous.

\section{References}

AWARDS

COMPETITION

Main Prize for Best Feature Film

Schiza (Schizo, Kazakhstan-Russia-France-Germany), Guka Omarova

Special Prize for Best Director

Somnambuul (Broken Sleep, Estonia-Finland), Sulev Keedus

Special Prize for an Outstanding Artistic Contribution

Ta divna Splitska noc (A Wonderful Night in Split, Croatia), Arsen Anton Ostojec

Special Mention

Wesele (The Wedding, Poland), Wojtek Smarzowski

Main Prize for Best Short Film

Jestes tam (You Are There, Poland), Anna Kazejak

Special Prize

Vonaton (On a Train, Hungary), Barabas Toth

Special Mention

Srce je kos mesa (The Heart Is a Piece of Meat, Slovenia), Jan Cvitkovic

OTHER FESTIVAL AWARDS

FIPRESCI Prize (International Critics)

Kontroll (Control, Hungary), Antal Nimrod 
Ecumenical Prize

Kontroll (Control, Hungary), Antal Nimrod

Don Quixote Prize - International Federation of Film Clubs

Schiza (Schizo, Kazakhstan-Russia-France-Germany), Guka Omarova

Promotion Prize of DEFA Film Foundation

Jubilate (Germany), Irma-Kinga Stellmach

Dialogue Prize for Intercultural Communication

Svoi (Our Own, Russia), Dmitry Meskhiev

Cottbuser Student Jury Award

Kontroll (Control, Hungary), Antal Nimrod

Cottbuser Filmschau Audience Award

Vier zu viel (Four Too Many, Germany), Stefanie Jaehde

\section{Author Information}

Ron HOLLOWAY (1933-2009) was an American critic, film historian, filmmaker and correspondent who adopted Europe as his home in the early fifties and spent much of his life in Berlin. He was an expert on the study of German cinema and against all odds produced, with his wife Dorothea, the journal German Film, keeping us up-to-date with the work of directors, producers and writers and the showing of German films around the world.

In 2007, Ron Holloway and his wife were awarded the Berlinale Camera Award. Ron also received the Bundesverdienstkreuz (German Cross of Merit), Polish Rings, Cannes Gold Medaille, the American Cinema Foundation Award, the Diploma for Support of Russian Cinema and an honorary award from the German Film Critics' Association.

Ron was also a valued contributor to Kinema for the past fifteen years. 